\section{Czech Culture under German Rule}

DR. Beneš has written a restrained but authenticated account of some of the Nazi crimes in a pamphlet (London: Allen and Unwin. 6d.) which has just appeared. It was the pride of the Czech nation that its culture, bound by numerous traditional ties with Britain and the West, was acknowledged by the whole civilized world. Now, after more than a year of German occupation, relics alone remain. The Nazis have attacked all sections of cultural life in an attempt to destroy the fundamentals of. Czech national ideals. Besides the universities and colleges, many schools are closed and modern educational buildings used as barracks, so that the education of Czech children is impossible. The dictum of the Nazi commissioners is that "for the Czechs as an Arbeitervolk elementary schools are sufficient". These serve for mass Germanization. School books have been "revised", and new ones with Nazi theories are systematically imposed upon the nation.

Meanwhile, twenty thousand students have been driven from their lecture rooms, and those employers who tried to alleviate their lot by giving them employment have been punished. Scientific equipment has been destroyed, valuable libraries wrecked and books and volumes of scientific journals burned or at best carried off to Germany. Results of years of research by Czech professors lie as rubbish on the floors of the lecture rooms and laboratories. The professors (some hundreds) and their assistants (about a thousand) were not allowed to take even their private possessions and note-books from their rooms; many have been sent to concentration camps and others given minor duties in administrative offices for which they were not fitted. The pamphlet merits the attention of learned men throughout the world and should arouse them to the danger now facing civilization.

\section{Seasonal Mortality in England and the United States}

SEASONAL variation of mortality has long been a fact of common knowledge, and its cause the subject of speculation. The maximum invariably falls in the first quarter of the year and the minimum in the third quarter. The difference between the two quarters is considerable; in 1931-35 the maximum was 60 per cent greater than the minimum. Is there any way, it may be asked, of reducing this difference, or is the winter excess due to causes of death over which at present we have little means of control ? A comparison of the mortality figures of England and Wales with those of the United States shows that the winter peak is higher in the former, although in summer they fall to a lower point than the United States figures.

This seasonal difference of mortality in the two countries has been the subject of a detailed statistical study by Dr. Lewis-Faning (Medical Research Council, Spec. Rep. Series, No. 239. H.M. Stationery Office, 1940. 1s. net). He reaches the conclusion that the winter disadvantage and the summer advantage of Great Britain are not due to climatic factors only, but are both also dependent, at least in part, on factors of mortality preventable in some degree. Thus, the main contributors to the British unfavourable winter balance are influenza, respiratory tuberculosis, bronchitis and pneumonia, and it has long been held that the last-named is at least partially preventable. The two most important contributors to our summer advantage are diseases of the heart and deaths from violence. The former shows a large decline in summer in both countries, the latter reveals no decided seasonal variation in Great Britain but a large summer rise in the United States. The relatively high rate of mortality from this cause in the United States is clearly one that may be open to attack.

\section{Cambridge University Botanic Garden}

BOTANICAL gardens contribute living interest to the teaching of plant science, and it is significant that their development began in the earliest days of the study of botany. The University of Cambridge was not one of the first bodies to recognize the value of providing living plants for study, but it had some early associations with botanical science. Mr. F. G. Preston has published an interesting paper on the history of the gardens now under his charge $(J$. Roy. Hort. Soc., 65, Pt. 6, June 1940). The famous Gerard attempted to establish a botanical garden at Cambridge in 1588, but without success. John Ray studied the Cambridgeshire flora, and later handed his mantle to the University's professor of botany, John Martyn, who extended the floral studies to other counties, and lived to see the first botanic garden at his University. In 1762, Dr. Walker, vicemaster of Trinity College, obtained about five acres of land, on the advice of his friend, Philip Miller of Chelsea. The garden remained in poor condition until 1831, when Prof. Henslow was successful in obtaining the present site, and transferred the plants to their new surroundings. The names of Babbington, Lynch, Marshall Ward and Sir Albert Seward show to what extent the directors of the garden have contributed to the development of modern science, and in more recent times W. Bateson and Prof. R. C. Punnett have worked there. Development after the War of 1914-18 was along the lines of closer contact with the teaching of botany, and was associated particularly with the names of Reginald Cory and Humphrey Gilbert-Carter.

\section{Accessions to the Fitzwilliam Museum, Cambridge}

The annual report of the Fitzwilliam Museum, Cambridge, for the year ending December 31, 1939, includes in a considerable list of accessions in the period a number of no little archæological interest and importance. Among these a bequest of an Egyptian bronze cat of the Twenty-sixth Dynasty by the late Claude G. Montefiore is said to be "the best of the type in the department". A steatite figure of Amen-ra and a hæmatite amulet of Ta-urt given by the director (Mr. L. G. C. Clarke) were the only further additions to the Egyptian antiquities apart from a valuable collection of choice specimens given by Mr. G. D. Hornblower. Mr. Hornblower was 
also the donor of two Chinese paintings on silk, a makimono and a sketch-book by Hokusai, another Japanese sketch-book, two Persian miniatures and a Coptic iron cross.

The Oriental Department also received some notable examples of Chinese ceramic art made specially for export, among these a porcelain bowl made for the Siamese market, given by Prof. Ellis H. Minns, of Pembroke College, and from the Hon. Lady Darwin another porcelain bowl which had been made for the European market, while an unusual punch bowl, intended for the same destination, was bequeathed by the late Lieut.-Colonel K. Dingwall. A Kutahia cup was a donation from Prof. Percy E. Newberry. In the Greek and Roman Department the most important acquisition was a fine south Italian bronze cinerary urn of the late sixth century B.c., purchased at the W. R. Hearst sale out of the Greek Antiquities Fund. Miss Winifred Lamb, honorary keeper of the Department, presented a Falisean skyphos of the fifth or fourth century B.c.

\section{British Museum Library Extension}

THE 'Iron Library' extension, which is now being completed at the British Museum, London, by H.M. Office of Works, is an interesting development in the introduction of welded steel work. The present structure is in the nature of an innovation, as it is the first example of an all-welded structural frame to be adopted by the Office of Works. The main factors influencing this decision were the greater neatness of the welded joint and the saving in headroom which it permits. It was designed to augment the bookshelf capacity of the Library. The extension occupies the north-east quadrant of the rectangular plot surrounding the historic Circular Reading Room and replaces a part of the existing structure of wrought iron and timber. In Electric Welding of May 1940, published quarterly by the Quasi-Arc Co., Ltd., of Bilston, Staffs., an instructive technical description, with photographs, is given of the building during the process of construction. Messrs. Dorman Long and Co., Ltd., are the constructors for the structural steel-work. They prepared and rolled the special sections; more than 500 tons of steel-work were necessary. Each welded joint was made in three runs from a No. 10 gauge electrode. The total number of welds in the structure exceeds 60,000 . The welding has been carried out with a maximum of ten operators, who between them have used about 47,000 quasi-arc electrodes. The necessary welding current was drawn from quasi-are Diesel, petrol and transformer units.

\section{Meteorology in Southern Rhodesia}

THE meteorological report for Southern Rhodesia for the year ended June 30, 1939, by R. A. Jubb, acting chief meteorologist, is dated January 1940 , but follows the general lines of those of pre-War years. Seasonal forecasts of rainfall of the type made by Sir Gilbert Walker, based on past departures from normal of meteorological elements $n$ selected action centres in other parts of the world, were continued, and were very successful in this year. The average rainfall over Southern Rhodesia during those months that correspond roughly with the winter of 1938-39 in the northern hemisphere, that is, Southern Rhodesia's summer rainfall of 1938-39, was forecast as 11.8 in. above normal ; actually it proved to be $12 \cdot 2$ in. above normal. This was the third year in succession during which the method was strikingly successful, and it is easy to believe that, as stated in the report, the forecasts are being found to be of practical value; there appears to be no sign that the correlation coefficients on which the forecasts are based are becoming smaller, as is sometimes the case after a considerable number of years of high correlation, for the least successful forecasting period of three years ended four years earlier. In Southern Rhodesia rain is of paramount interest, and it is satisfactory to note that whereas thirteen observing stations closed down, the number of new stations was forty-one.

\section{Map of the Karakoram}

A NEW map of the Karakoram has been published by the Royal Geographical Society (7s. 6d. or R. 5). Produced under the direction of Prof. K. Mason, it incorporates all published results of exploratory work up to Mr. E. Shipton's expedition of 1937. The scale is 1 to 750,000 and the size of the sheet is about twenty by twenty-three inches. The great altitude range from about $3,000 \mathrm{ft}$. to $28,000 \mathrm{ft}$. presented a difficult problem in representing relief. The layer colour system had to be abandoned. The contours in a region of such high relief are too close and the tint of the layer merged into the colour of the contour line. Moreover a satisfactory scheme of colour could not be found. Hill slopes are shaded with brown and purple on a general ground tint of yellow and generally the shading is cast from the north-west, but the direction varies slightly to suit the slope of the ground. Blue shading is used for snow and glaciers are white. Valleys have a layer tint of greyish-green. There are altogether eight colours and the map is a most effective piece of work. Heights are given in feet and the names employed are those decided on by the Karakoram Conference of 1937 and approved by the SurveyorGeneral of India.

\section{Metal Water-Jet Pump}

Aцтнолgh metal filter-pumps have been in common use for some time, the majority were imported. A new model developed and produced in Great Britain is now available. Metal filter-pumps are unbreakable and easily cleaned. In addition, the jet of the new model has been re-designed so that a high pumping speed can be reached even with pressures as low as $15 \mathrm{lb}$. in the water supply. Under suitable conditions, pressures of $15 \mathrm{~mm}$. or less of mercury are reached. The new pump should therefore prove of great service in general laboratory work involving distillations, filtrations or aerations and in hospital and surgical work. The pump and further details can be obtained from Messrs. W. Edwards and Co., Ltd., Southwell Road, London, S.E.5. 